\title{
Effect of Thiamine on the L-Malate Fermentation by Schizophyllum commune
}

\author{
Sei Tachibana AND JiUichi Siode ${ }^{2}$ \\ Department of Chemistry, Faculty of Science and Engineering, \\ Ritsumeikan University, Kita-ku, Kyoto (Post No. 603)
}

(Received September 20, 1971)

\begin{abstract}
It was found that Schizophyllum commune which produced L-malate through $\mathrm{CO}_{2}$-fixation process with a phosphoenolpyruvate carboxytransphosphorylase-like enzyme required thiamine. Upon the addition of oxythiamine at a concentration of $100 \mu \mathrm{g} / 100 \mathrm{ml}$, both the L-malate production and the glucose consumption were inhibited about $50 \%$, while the conversion of glucose to L-malate was inhibited only $10 \%$. The optimum concentration of thiamine to be added in the medium for the L-malate fermentation was $0.5 \mu \mathrm{g} / 100 \mathrm{ml}$. Upon the addition of $100 \mu \mathrm{g} / 100$ $\mathrm{ml}$ thiamine, both the yield of L-malate and the conversion degree of glucose to L-malate were reduced about $50 \%$, while the glucose consumption was not affected. One of the effects of thiamine appears to be a stimulative action on pyruvate decarboxylation. The optimum amount of thiamine to be added for the growth of the mold seemed to be more than $10 \mu \mathrm{g} / 100 \mathrm{ml}$.
\end{abstract}

It was previously reported that Schizophyllum commune IFO 4928, a Basidiomycete, produced L-malate as much as over $90 \%$ of glucose consumed through $\mathrm{CO}_{2}$-fixing process $(1,2)$.

The effect of thiamine on the L-malate fermentation was investigated, since a certain amount of oxythiamine inhibited the growth of the mold. It was proved that there existed an optimum concentration of thiamine to be added in the medium for the L-malate fermentation, which was much lower than the optimum concentration for the growth of the mold.

\section{EXPERIMENTAL}

\section{Microorganism}

Two strains, Schizophyllum commune IFO 4928 and IFO 6138 were used. Schizophyllum commune IFO 4928 was found to produce mainly L-malate through reductive carboxylation of phosphoenolpyruvate coupled with glyceraldehyde dehydrogenase (3). The main product of the strain IFO 6138 was pyruvate (4). The stock cultures of the strain were maintained on the slants of malt extract agar, or of synthetic medium composed of glucose $3 \mathrm{~g}$, peptone $0.2 \mathrm{~g}, \mathrm{NH}_{4} \mathrm{NO}_{3} 0.1 \mathrm{~g} \mathrm{KH}_{2} \mathrm{PO}_{4} 0.1 \mathrm{~g}$,

\footnotetext{
${ }^{1}$ Studies on $\mathrm{CO}_{2}$-fixing fermentation. XV. This work was supported by Grant No. 58135 of the Ministry of Education, Japan (1963). This paper was presented at the 17 th Annual Meeting of Vitamin Society of Japan (May 1965), abstract: Vitamins 32, 152 (1965).

2 立花 精, 塩出十一

Abreviation: PEP, phosphoenolpyruvate; $\mathrm{Pi}$, orthophosphate; OAA, Oxaloacetate; PPi, inorganic pyrophosphate; GAP, glyceraldehyde 3-phosphate; 1, 3-dipGA, 1, 3-diphosphoglycerate.
} 
$\mathrm{MgSO}_{4} \cdot 7 \mathrm{H}_{2} \mathrm{O} 0.05 \mathrm{~g}, \mathrm{KCl} 0.05 \mathrm{~g}$, agar $1.5 \mathrm{~g}$ and tap water $100 \mathrm{ml}$.

\section{Chemicals}

Thiamine- $\mathrm{HCl}$ was purchased from Wako Junyaku Co., Ltd. Oxythiamine was a generous gift from Dr. S. Fukui, Kyoto University. Other reagents were of analytical grade.

\section{Preparation of Seed Culture}

The mold was grown on a solid culture consisting of wheat bran, pine wood-powder and water $(1: 1: 2)$ for about two weeks at $30^{\circ}$.

\section{Fermentation Procedure}

The basal medium used was composed of glucose $5 \mathrm{~g}, \quad \mathrm{NH}_{4} \mathrm{NO}_{3} \quad 0.1 \mathrm{~g}, \quad \mathrm{KH}_{2} \mathrm{PO}_{4} \quad 0.1 \mathrm{~g}$, $\mathrm{MgSO}_{4} \cdot 7 \mathrm{H}_{2} \mathrm{O} 0.05 \mathrm{~g}, \mathrm{KCl} 0.05 \mathrm{~g}, \mathrm{MnSO}_{4} 0.15$ $\mathrm{mg}, \mathrm{CaCO}_{3} 5 \mathrm{~g}$ and tap water $100 \mathrm{ml}$. Sixty milliliters of this medium in a $500 \mathrm{ml}$ shaking flask was inoculated with about $0.3 \mathrm{~g}$ of the solid culture or three loopfuls of the slant culture, and then cultured on a reciprocal shaker at $28-30^{\circ}$.

\section{Analysis}

L-Malic acid was determined manometrically using the malic enzyme of Lactobacillus arabinosus (5). Pyruvate was measured colorimetrically according to the method of Friedemann and Haugen (6). Residual glucose was determined by the modified method of Bertrand (7). Mycelia were washed, and dried for 60 minutes at $105^{\circ}$.

\section{RESUlTS}

\section{Effect of Oxythiamine}

Oxythiamine was employed as an antagonist of thiamine, because it was assumed that the solid culture composed of wheat bran and pine wood-powder should contain an adequate amount of thiamine which might affect on the L-malate fermentation of the strain IFO 4928. The effect of oxythiamine was studied using the basal medium containing the graded amounts of $10-500$ $\mu \mathrm{g} / 100 \mathrm{ml}$ of the compound to which the solid seed culture of IFO 4928 strain was inoculated. The inhibitory effect of oxythiamine on the glucose consumption by this strain was so remarkable that the addition of $200 \mu \mathrm{g} / 100 \mathrm{ml}$
TABLE 1

The effect of oxythiamine on the L-malate fermentation by Schizophyllum commune IFO $4928^{a}$

\begin{tabular}{ccrccccr}
\hline $\begin{array}{l}\text { Oxythia- } \\
\text { mine } \\
\text { added }\end{array}$ & $\begin{array}{c}\text { L-Malate } \\
\text { produced }\end{array}$ & $\begin{array}{c}\text { per } \\
\text { cent } \\
\text { ratio }\end{array}$ & $\begin{array}{c}\text { Glucose } \\
\text { consumed }\end{array}$ & $\begin{array}{c}\text { per } \\
\text { cent } \\
\text { ratio }\end{array}$ & Conver \\
sion & $\begin{array}{c}\text { per } \\
\text { cent } \\
\text { ratio }\end{array}$ \\
\hline$\mu g / 100 m l$ & $m g / 100 m l$ & & $m g / 100 m l$ & \multicolumn{4}{c}{ per cent } \\
0 & $2067 \pm 283$ & 100 & $3562 \pm 237$ & 100 & 57.8 & 100 \\
50 & $1405 \pm 80$ & 68 & $2907 \pm 242$ & 82 & 48.4 & 84 \\
100 & $1046 \pm 36$ & 51 & $1960 \pm 160$ & 55 & 53.7 & 93 \\
200 & $944 \pm 19$ & 47 & $1820 \pm 20$ & 51 & 51.9 & 90 \\
400 & $746 \pm 162$ & 36 & $1511 \pm 469$ & 42 & 50.9 & 88 \\
500 & $582 \pm 80$ & 28 & $1120 \pm 120$ & 31 & 51.8 & 89 \\
\end{tabular}

a Cultured for 7 days at $30^{\circ}$, using the solid seed culture

of the antagonist resulted in a $50 \%$ suppression, as shown in Table 1. Nevertheless, the conversion degree of glucose to L-malic acid was not so inhibited, suggesting that the L-malate forming process was not affected by the addition.

2. Effect of Thiamine on $L$-Malate Fermentation

When a few loopfuls of the slant culture was used as a seed in place of the solid seed culture, the growth of the strain was very poor. Both the growth and L-malate fermentation were stimulated by the addition of thiamine in amounts of $10-400 \mu \mathrm{g} / 100 \mathrm{ml}$ as shown in Table 2 , whereas the conversion rate to L-malate of glucose was somewhate lower than that obtained with the solid seed as shown in Table 1 . The addition of much lower concentrations of thiamine was tested in order to increase the yield

TABLE 2

The effect of thiamine on the L-malate fermentation by Schizophyllum commune IFO $4928^{a}$

\begin{tabular}{ccccccr}
\hline $\begin{array}{c}\text { Thiamine } \\
\text { added }\end{array}$ & $\begin{array}{c}\text { L-Malate } \\
\text { prodced }\end{array}$ & $\begin{array}{c}\text { per } \\
\text { cent } \\
\text { ratio }\end{array}$ & $\begin{array}{c}\text { Glucose } \\
\text { consumed }\end{array}$ & $\begin{array}{c}\text { per } \\
\text { cent } \\
\text { ratio }\end{array}$ & $\begin{array}{l}\text { Conver- } \\
\text { sion }\end{array}$ & $\begin{array}{c}\text { per } \\
\text { cent } \\
\text { ratio }\end{array}$ \\
\hline$\mu g / 100 m l$ & $m g / 100 m l$ & & $m g / 100 m l$ & \multicolumn{3}{c}{ per cent } \\
0 & 38 & 20 & 558 & 13.7 & 6.8 & 14 \\
10 & 1941 & 100 & 4090 & 100 & 47.5 & 100 \\
60 & 1600 & 83 & 3652 & 89 & 43.9 & 93 \\
100 & 1610 & 83 & 3754 & 92 & 42.8 & 91 \\
200 & 1380 & 71 & 3630 & 89 & 37.9 & 80 \\
400 & 1400 & 72 & 3620 & 88 & 38.8 & 82 \\
\hline
\end{tabular}

Values are the average of the results obtained with three experiments.

a Cultured for 8 days at $28^{\circ}-30^{\circ}$, using the slant seed culture 
TABLE 3

The optimum concentration of thiamine added in the medium for L-malate fermentation of Schizophyllum commune IFO $4928^{a}$

\begin{tabular}{cccccc}
\hline $\begin{array}{c}\text { Thiamine } \\
\text { added }\end{array}$ & $\begin{array}{c}\text { L-Malate } \\
\text { produced }\end{array}$ & \multicolumn{2}{c}{$\begin{array}{c}\text { Glucose } \\
\text { consumed }\end{array}$} & \multicolumn{2}{c}{ Conversion $\begin{array}{c}\text { per cent } \\
\text { ratio }\end{array}$} \\
\hline$\mu g / 100 m l$ & $m g / 100 m l$ & $m g / 100 m l$ & per cent & \\
0 & $40.1 \pm 27.7$ & $441 \pm 9$ & 9.1 & 13.1 \\
0.1 & 2257 & \pm 107 & $3772 \pm 281$ & 59.9 & 86.5 \\
0.5 & 2902 & \pm 117 & $4192 \pm 74$ & 69.3 & 100 \\
1.0 & 2035 & \pm 330 & $3894 \pm 86$ & 52.1 & 75.1 \\
10.0 & 1908 & \pm 310 & $4564 \pm 17$ & 41.7 & 60.1 \\
50.0 & 1805 & \pm 195 & $4650 \pm 175$ & 39.5 & 57.0
\end{tabular}

a Cultured for 8 days at $28^{\circ}-30^{\circ}$, using the slant seed culture

TABLE 4

The effect of thiamine on the pyruvate production by Schizophyllum commune IFO $6138^{a}$

$\begin{array}{cccccc}\begin{array}{c}\text { Thiamine } \\ \text { added }\end{array} & \begin{array}{c}\text { L-Malate } \\ \text { produced }\end{array} & \begin{array}{c}\text { Glucose } \\ \text { consumed }\end{array} & \begin{array}{l}\text { Conver- Pyruvate Conver- } \\ \text { sion }\end{array} \\ \text { produced sion }\end{array}$

a Cultured for 10 days at $28^{\circ}-30^{\circ}$, using the slant seed culture

of L-malate. As shown in Table 3, the optimum concentration of thiamine to be added for the enhancement of L-malate yield was found to be as little as $0.5 \mu \mathrm{g} / 100 \mathrm{ml}$, while a larger amount of thiamine was preferable for the glucose consumption of this strain. It was, therefore, assumed that the stimulative effect of thiamine on the glucose consumption would be attributable to its stimulative effect on the oxidative decarboxylation of pyruvate. Accordingly, Schizophyllum commune IFO 6138 which produced much more pyruvate rather than L-malate was employed to clarify the function of thiamine. As shown in Table 4, the amount of pyruvate was markedly decreased upon the addition of $10 \mu \mathrm{g} / 100 \mathrm{ml}$ of thiamine, while the L-malate production was not so reduced. Consequently, it was suggested that the pyruvate dehydrogenation would be accelerated by the addition of thiamine, causing the stimulation of glucose consumption.
TABLE 5

The effect of thiamine on the growth of Schizophyllum commune IFO 4928

\begin{tabular}{|c|c|c|c|c|c|c|}
\hline & $\begin{array}{c}\text { Thiamine } \\
\text { added }\end{array}$ & $\mathrm{pH}$ & $\begin{array}{c}\text { Mycelial } \\
\text { weight }\end{array}$ & $\begin{array}{l}\text { Glucose } \\
\text { consumed }\end{array}$ & $\begin{array}{l}\text { Conver- } \\
\text { sion }\end{array}$ & $\begin{array}{l}\text { L-Malate } \\
\text { produced }\end{array}$ \\
\hline & $\mu \mathrm{g} / 100 \mathrm{ml}$ & & $\mathrm{mg} / 100 \mathrm{ml}$ & $\mathrm{mg} / 100 \mathrm{ml}$ & per cent & \\
\hline \multirow{4}{*}{ A } & 0 & 3.9 & 62 & - & - & trace \\
\hline & 0.5 & 4.1 & $195 \pm 6$ & $501 \pm 20$ & 38.8 & trace \\
\hline & 10.0 & 4.1 & $245 \pm 14$ & $608 \pm 86$ & 40.9 & trace \\
\hline & 50.0 & 3.9 & $250 \pm 3$ & $811 \pm 50$ & 30.4 & trace \\
\hline \multirow{4}{*}{ B } & 0 & 2.2 & 17 & - & - & trace \\
\hline & 50 & 2.3 & $139 \pm 9$ & $915 \pm 54$ & 15.2 & trace \\
\hline & 500 & 2.3 & $158 \pm 48$ & $1482 \pm 308$ & 10.6 & trace \\
\hline & 1000 & 2.4 & $117 \pm 10$ & $1173 \pm 250$ & 10.2 & trace \\
\hline
\end{tabular}

A Cultured for 7 days at $28^{\circ}-30^{\circ}$, using the slant seed culture

B Cultured for 8 days at $28^{\circ}-30^{\circ}$, using the slant seed culture

\section{Effect of Thiamine on Growth}

By using a $\mathrm{CaCO}_{3}$-free medium, it was shown that the effect of thiamine on the growth of Schizophyllum commune IFO 4928 was not comparable to the effect on the L-malate production, as shown in Table 5 . The optimum amount, $0.5 \mu \mathrm{g} / 100 \mathrm{ml}$ for L-malate production would not be sufficient for the optimum growth, which may require more than $50 \mu \mathrm{g} /$ $100 \mathrm{ml}$. Moreover, it was proved that no significant inhibition of growth was observed upon the addition of as much as $1 \mathrm{mg} / 100 \mathrm{ml}$ thiamine.

\section{Discussion}

In our preceding papers $(2,3)$, the main process of the L-malate fermentation of Schizophyllum commune was proposed as follows:

$$
\begin{aligned}
& \mathrm{PEP}+\mathrm{CO}_{2}+\mathrm{Pi} \rightarrow \mathrm{OAA}+\mathrm{PPi} \\
& \mathrm{GAP}+\mathrm{Pi}+\mathrm{NAD}+\mathrm{OAA} \rightarrow \\
& \text { 1,3-dipGA }+\mathrm{NAD}+\mathrm{L}-\text { Malate }
\end{aligned}
$$

Equation (1) is catalyzed by a phosphoenolpyruvate carboxytransphosphorylase-like enzyme. Equation (2) shows a malic dehydrogenase reaction coupled with glyceraldehyde dehydrogenase linked by NAD. The larger part of the amount of L-malate which was produced under the addition of $0.5 \mu \mathrm{g} / 100 \mathrm{ml}$ thiamine would be formed from phosphoenolpyruvate via the abovementioned two reactions, while the smaller part of the amount which was diminished under the 
addition of $1 \mu \mathrm{g} / 100 \mathrm{ml}$ thiamine would be formed from pyruvate by a pyruvate carboxylase.

Moreover, it seemed reasonable to assume that the more decrease of L-malate production upon the addition of over $10 \mu \mathrm{g} / 100 \mathrm{ml}$ thiamine would be attributed to the more acceleration of pyruvate dehydrogenation which might cause a stimulation of pyruvate kinase followed by an impediment of phosphoenolpyruvate carboxylation.

\section{ACKNowledgement}

The authors express their thanks to Prof. Dr. S. Fukui, Kyoto University for his kind gift of oxythiamine.

\section{REFERENCES}

1. Tachibana, S., Hakko Kogaku Zassi, 45, 353 (1967).

2. Tachibana, S., Umehara, K., and Siode, J., Hakko Kogaku Zassi, 45, 1040 (1967).

3. Tachibana, S., Siode, J., and Hanai, T., J. Ferment. Technol., 45, 1130 (1967).

4. Tachibana, S., and Siode, J., J. Vitaminol., 15, 51 (1969).

5. Nossal, P.M., Biochem. J., 49, 407(1951).

6. Friedemann, T.E., and Haugen, G. E., J. Biol. Chem., 147, 415 (1943).

7. Henmi, T., and Tomoeda, M., Nogei Kagaku Zassi, 19, 381 (1943). 